\title{
Circulating Tumor Cells for Glioma
}

\author{
Huikai Zhang, Fanen Yuan, Yangzhi Qi, Baohui Liu* and Qianxue Chen* \\ Department of Neurosurgery, Renmin Hospital of Wuhan University, Wuhan, China
}

Liquid biopsy has entered clinical applications for several cancers, including metastatic breast, prostate, and colorectal cancer for CTC enumeration and NSCLC for EGFR mutations in ctDNA, and has improved the individualized treatment of many cancers, but relatively little progress has been made in validating circulating biomarkers for brain malignancies. So far, data on circulating tumor cells about glioma are limited, the application of circulating tumor cells as biomarker for glioma patients has only just begun. This article reviews the research status and application prospects of circulating tumor cells in gliomas. Several detection methods and research results of circulating tumor cells about clinical research in gliomas are briefly discussed. The wide application prospect of circulating tumor cells in glioma deserves further exploration, and the research on more sensitive and convenient detection methods is necessary.

OPEN ACCESS

Edited by:

Maria Caffo,

University of Messina, Italy

Reviewed by:

Güliz Acker,

Charité Medical University of

Berlin, Germany

Claudia Katharina Petritsch,

Stanford University, United States

${ }^{*}$ Correspondence:

Baohui Liu

bliu666@whu.edu.cn

Qianxue Chen

chenqx666@whu.edu.cn

Specialty section:

This article was submitted to Neuro-Oncology and Neurosurgical

Oncology,

a section of the journa

Frontiers in Oncology

Received: 16 September 2020

Accepted: 11 February 2021

Published: 10 March 2021

Citation:

Zhang H, Yuan F, Qi Y, Liu B and Chen Q (2021) Circulating Tumor Cells

for Glioma. Front. Oncol. 11:607150.

doi: 10.3389/fonc.2021.607150
Keywords: glioma, circulating tumor cells, liquid biopsy, blood, biomarker

\section{INTRODUCTION}

Glioma is the most common malignant brain tumor, with 200,000 patients diagnosed worldwide each year (1). Among all primary central nervous system tumors, $47.7 \%$ of those are glioblastomas (GBM), its incidence increases with age, and its characteristic histopathology include high mitotic activity, extensive necrosis and microvascular hyperplasia (2-4). Glioma has a poor prognosis and often relapses. Over time, the degree of malignancy tends to increase. Most brain malignant tumors are mainly treated with surgical resection, combined with radiotherapy, chemotherapy, and other comprehensive treatment methods, but the current treatment effect is poor. The median overall survival of high-grade glioma is 14-17 months (1). At present, the main auxiliary diagnostic means are imaging evaluation and pathological diagnosis. The treatment effect of glioma patients is evaluated by the response to tumor radiological appearance on MRI images $(5,6)$. However, there is a response of treatment-related brain tissue to chemotherapy and radiation therapy, known as pseudoprogression, and the pseudoprogression can cause enhancements and edema increase just like tumor progression on MRI $(7,8)$. The condition may be caused by treatment-related localized inflammation, which leads to edema and increased abnormal vascular permeability. At present, there are no biomarkers or imaging or clinical patterns that can reliably distinguish glioma recurrence from pseudoprogression, or monitor treatment effectiveness.

Recently, there has been a new minimally invasive tool to get information about tumor: liquid biopsies (9). Different types of circulating biomarkers that were associated with tumor, were identified in the serum and cerebrospinal fluid, including circulating tumor cells (CTCs), exosomes (microvesicles), circulating nucleic acids (DNA, RNA, and miRNA), proteins, and metabolites (10). These biomarkers, which rely on reliable detection means in the blood or cerebrospinal fluid, are relatively easy to obtain, allow for repeated measurements, and are significantly better to monitor disease.

Currently, many techniques have been developed for separating CTC from abundant leukocytes and erythrocytes. The physical-based separation depends on the size, deformability, density, or 
the dielectric properties of CTC different from normal blood cells (11). Epithelial cell adhesion molecule (EpCAM) is often used as a target for CTC enrichment because it is widely expressed on the cell surface of cancer cell-derived CTCs and has not been detected on normal blood cells (12). Anti- EpCAM antibodies can be used to directly detect or enrich CTC, while removing other cells by using anti-CD45 antibodies (specific for leukocytes). Different types of nanomaterials, such as magnetic nanoparticles (MNPs), gold nanoparticles (AuNPs), which can promote cell adhesion and have been reported for CTC detection (13). A variety of detection methods are used for CTC detection, but due to the complexity of the operation or lack of specificity, CTC cannot be widely used. Fast, convenient, and highly specific detection methods are still the limitations of CTC research.

Liquid biopsy has entered clinical applications for several cancer types, including breast and colorectal cancer, and has improved the individualized treatment of many types of cancer, but relatively little progress has been made in validating circulating biomarkers for brain malignancies. This review outlines the current status of the developments of circulating tumor cells for glioma.

\section{CIRCULATING TUMOR CELLS}

Circulating Tumor Cells (CTCs) are tumor cells which existing in the human circulatory system and have three typical characteristics: Originating from the primary tumor or metastases; Appearing in blood vessels and Participating in blood circulation (14). They are considered to be extremely harmful because it is an important cause of distant metastasis and death of malignant tumors. CTCs exhibit a variety of advanced properties, such as epithelial-mesenchymal transition (EMT) and dormancy, that are essential to support their survival in the bloodstream, radiological, and chemical resistance, escape from the anti-cancer immune response, and metastasis (15). CTCs that from primary or metastatic lesions and with long-term survival in the blood circulation system represent the most aggressive subcloning of tumor cells. Precise molecular typing of these tumor cells can help clinicians to diagnose metastatic or recurrence, and can be used to monitor the degree of disease progression and treatment response. However, most CTCs are rapidly destroyed in the circulation, and the metastatic potential appears to be limited. Only $2.5 \%$ of CTCs were shown to form micrometastases, and only $0.01 \%$ of these cells can induce macrometastases (16).

A large number of clinical trial data have proved that CTC is an independent prognostic factor, a marker and target for targeted therapy in patients with advanced breast cancer, lung cancer and prostate cancer (17-19). Though peripheral metastasis to glioma is considered rare, CTCs have been detected in the blood of glioma patients (20), and many isolated cases of glioma metastasis have been reported (21). Therefore, the identification of CTCs in glioma patients has important clinical application value for early tumor diagnosis and the prognosis. Even many molecular characteristics of gliomas such as the combined deletion of $1 \mathrm{p} / 19 \mathrm{q}$, IDH1 mutations, and hypermethylation of the MGMT promoter are expected to be detected in circulating tumor cells in peripheral serum of glioma patients. So far, data on CTCs about glioma are limited, the application of CTCs as biomarker for glioma patients has only just begun, and the requirements for the specificity of the detection technology are more important.

\section{DETECTION METHODS OF CTCs IN GLIOMA}

\section{GFAP-Positive as a Marker}

Muller et al. used immunostaining against GFAP as a GBM marker and detected CTCs in 29 of 141 (20.6\%) GBM patients (22). Glial fibrillary acidic protein (GFAP) is the main intermediate filament of mature and developing astrocytes, and is the most specific diagnostic marker for GBM cells. The serum concentration of GFAP measured by enzyme-linked immunosorbent assay is considered as a diagnostic marker for GBM $(23,24)$. The GFAP-positive cells be used for gene sequencing analysis and then found that the detected CTC cells had EGFR gene amplification similar to that of the primary tumor, deletion of chromosome 7 and 10 fragments, etc.

However, the expression of GFAP is not limited to glial cells, such as hepatic stellate cells (25), so it is necessary to eliminate interference from a small fraction of $\mathrm{GFAP}^{+}$cells from other cells. At the same time, the study is limited to GBM, and the positive rate is very low.

\section{Telomerase-Based Assay}

Kojima and colleagues engineered an adenovirus containing the gene for GFP that can selectively replicate in cells that express telomerase (26). MacArthur et al. (27) used a telomeraseresponsive adenoviral probe that consist of the expression cassette for GFP and hTERT promoter, to detect CTCs. Telomerase has a catalytic subunit with reverse transcriptase activity (hTERT), and its expression is almost exclusively confined to cancer cells $(28,29)$. Telomerase and hTERT expression are closely related in human cancers but not observed in most normal tissues (30). Because well-differentiated WBCs typically do not express telomerase, the fluorescence detected can help distinguish CTCs from non-cancerous cells found in the blood. At the same time, experimentally verified that the tumor cells with increased telomerase activity detected by the probe are consistent with the expression of Nestin and EGFR, which are overexpressed in gliomas (31-36). The major advantage of the telomere-based assay is that this method has high sensitivity (more than $90 \%$ of solid tumors, including gliomas, increased expression of telomerase) and high specificity (telomerase not expressed in highly differentiated and normal cells) (30), but the operation is complicated and expensive. Large sample validation is still required.

\section{Examination for Aneuploidy of Chromosome 8 by FISH}

Chromosome aberrations are unique characteristics of tumors and aneuploidy changes may lead to tumor development (37-44). The degree of chromosomal aberrations usually increases with tumor progression and is associated with poor prognosis (45). Tumors with aggressive clinical behavior are more likely to be aneuploid. Many studies have found that 
chromosome 8 has aneuploidy in many solid tumors, such as lung cancer, pancreas cancer, gastric cancer, colon cancer, and bladder transitional cell carcinoma et al., which provides feasibility for the detection of aneuploidy-based CTCs (4650).

Fluorescence in situ hybridization (FISH) analysis is a powerful tool for detecting numerical and structural chromosome aberrations using chromosome specific DNA probes on interphase nuclei of various tumors. Gao et al. used the CEP8-FISH to detect CTCs in the peripheral blood of glioma patients (20). And CTCs were detected in different pathological subtypes of glioma, which indicated CTCs should be the common property of glioma. The detection method does not depend on surface-related antigen expression or cell size of glioma cells, and has good sensitivity.

\section{CTC-iChip and Antibodies Cocktail}

The CTC-iChip is an integrated microfluidic platform, with its ability to isolate CTCs in suspension using both tumor antigendependent and tumor antigen-independent modes, is compatible with high-definition imaging and single-cell molecular analyses, as well as standard clinical cytopathology (51).

The CTC-iChip uses tagged antibodies against leukocyte surface markers CD45 and CD16 to efficiently remove leukocytes from blood, thereby enriching CTCs for immunofluorescence staining and molecular typing. Sullivan et al. developed a variety of specific antibodies that would identify GBM cells and complete absence in normal blood cells (52). Researchers chose five GBM specific antibodies including SOX2, Tubulin beta-3, EGFR, A2B5, and c-MET, annotated as STEAM, for simultaneous immunofluorescence staining. In the $33 \mathrm{GBM}$ patients, only $39 \%$ had detected CTCs at least once in an average 2.6 venous blood draws.

\section{Recombinant VAR2CSA Malaria Protein}

VAR2CSA malarial protein (rVAR2) has been used for CTC separation (53). The protein specifically binds to a unique chondroitin sulfate structure that is named oncofetal chondroitin sulfate (ofCS), which exists in the placenta and almost all cancer cells, and has limited expression in normal tissues (54). BangChristensen et al. (55) invented a CTC separation method that used magnetic beads to equip rVAR2 protein to capture CTCs from glioma patient blood samples. The study used ofCS as a target, not only for capture, but also for the detection of glioma CTC gene mutation. Only 10 glioma patient blood samples were tested. And there is no correlation between the number of CTCs and WHO grades.

\section{hTERT Promoter-Regulated Oncolytic Herpes Simplex Virus-1}

Adusumilli et al. (56) reported the use of tumor-selective HSV expressing GFP to detect cancer cells in body fluids. HSV-1 can targets cancer cells with telomerase-reverse-transcriptasepositive and recognize CTCs by expressing green fluorescent protein. Zhang et al. (57) established a highly applicable method based on oHSV1-hTERT-GFP, to selectively label CTCs in peripheral blood by expressing GFP. It can be monitored by flow cytometry or fluorescence microscopy and more accurately determine the number of CTCs in the peripheral circulation of glioma patients, and may determine the molecular typing and genetic profiling.

\section{Other Methods}

Krol et al. (58) used the Parsonrtix microfluidic cassette to ensure label-free physical capture of CTCs and CTCs were stained with a dedicated GBM CTC antibody cocktail containing antibodies against EGFR, Ki67, and EB1, as well as against the WBC marker CD45 to exclude leukocyte contamination. A novel aptamer combined with nanostructures improves affinity of CTCs capture (59). And a label-free separation microfluidic device was developed using multistage channel, which took full advantage of inertial lift force (60). These two methods are used to separate the mixture of human peripheral blood and glioma cell lines, which has high separation efficiency, simple operation and extremely low cost.

In fact, a wide variety of CTC enrichment approaches have been developed, but rarely applied to detect glioma cells. Due to the overlapping expression of markers in tumor cells and normal cells, the use of lineage markers to identify CTCs has some limitations. Further identification of CTCs at the DNA, RNA or protein level will help improve detection rates. There is still a need for more sensitive detection methods as well as clinical studies of large numbers of samples (Tables 1, 2 shows more details about detecting methods of CTCs in glioma patients).

\section{CHARACTERIZATION OF CTCS IN GLIOMA}

\section{Stem Cell-Like Properties}

Liu et al. (61) reported that GBM-derived CTC possessed a cancer stem cell (CSC)-like phenotype and contributed to local tumorigenesis and recurrence by the process of self-seeding. CSCs are characterized by strong self-renewal ability and higher malignant potential (62), and also show advanced resistance to radiation and chemotherapy (63). And CSCs can enter the circulation from the tumor body as CTC, survive in focal and systemic treatments, and reseed seeds for the primary tumor bed to generate new local tumors, providing an alternative source for tumor in situ invasion. At present, it is speculated that CSC-like CTCs may return to the tumor bed through this replay mechanism and refill, which may cause tumor recurrence or metastasis (61). Similarly, clinical and surgical pathological evidence suggests that GBM metastases are common in the brain, which may not be fully explained by direct invasion of tumor cells (64). We speculated that the continued spread of CTC on the primary tumor bed may lead to local micrometastasis. In addition, glioma CSCs have significantly upregulated Wnt signaling, which is essential for maintaining cell survival, inducing EMT, and tumorigenicity (65). Therefore, the elimination of CTCs with Wnt as the target may GBM's new treatment strategy.

\section{Mesenchymal Enrichment}

GBM has been classified by The Cancer Genome Atlas (TCGA) Consortium into four subtypes: classic, mesenchymal (MQ), 
TABLE 1 | Circulating tumor cells in glioma patients.

\begin{tabular}{|c|c|c|c|c|c|c|c|c|c|}
\hline References & $\begin{array}{l}\text { Source } \\
(\mathrm{ml})\end{array}$ & $\begin{array}{l}\text { Patients } \\
\text { types } \\
(\mathrm{T} / \mathrm{N})\end{array}$ & Time of take & Cell enrichment & $\begin{array}{l}\text { Cell } \\
\text { characterization }\end{array}$ & Results & $\begin{array}{l}\text { Treatment } \\
\text { response }\end{array}$ & $P$-value & Survival \\
\hline $\begin{array}{l}\text { Muller et al. } \\
\text { (22) }\end{array}$ & $\begin{array}{l}\text { Blood } \\
10 \mathrm{ml}\end{array}$ & $\begin{array}{l}\text { GBM } \\
141 / 23\end{array}$ & Pre/postoperative & $\begin{array}{l}\text { MNCs isolated by } \\
\text { gradient } \\
\text { centrifugation } \\
\text { Erythrocyte lysis }\end{array}$ & $\begin{array}{l}\text { Fluorescence } \\
\text { immunocytochemistry } \\
\text { GFAP+ and } \\
\text { CD45- }\end{array}$ & $\begin{array}{l}N=29 / 141 \\
(>1 \text { CTCs } / 10 \mathrm{ml})+\end{array}$ & $\begin{array}{l}\text { Pre/postoperative } \\
\text { (13.4\%) } \\
\text { Preoperative (6\%) } \\
\text { Postoperative (7.5\%) }\end{array}$ & $P>0.05$ & $\begin{array}{l}\text { Mean } \\
13.1 \text { Months } \\
P>0.05\end{array}$ \\
\hline $\begin{array}{l}\text { MacArthur } \\
\text { et al. (27) }\end{array}$ & $\begin{array}{l}\text { Blood } \\
10 \mathrm{ml}\end{array}$ & $\begin{array}{l}\text { WHO III/IV } \\
20 / 30\end{array}$ & $\begin{array}{l}\text { Pre/post- } \\
\text { radiotherapy }\end{array}$ & $\begin{array}{l}\text { Centrifuge in } \\
\text { OncoQuick tubes }\end{array}$ & $\begin{array}{l}\text { telomerase- } \\
\text { responsive } \\
\text { adenoviral probe }\end{array}$ & $\begin{array}{l}n=8 / 11 \\
\text { pre-radiotherapy } \\
n=1 / 8 \\
\text { post-radiotherapy } \\
(>1.3 \mathrm{CTCs} / \mathrm{ml})+\end{array}$ & $\begin{array}{l}\text { CTCs } \\
\text { (Pre-RT> } \\
\text { Post-RT) }\end{array}$ & $P<0.001$ & NA \\
\hline $\begin{array}{l}\text { Gao } \\
\text { et al. (20) }\end{array}$ & $\begin{array}{l}\text { Blood } \\
7.5 \mathrm{ml}\end{array}$ & $\begin{array}{l}\text { WHO II-IV } \\
31 / 10\end{array}$ & $\begin{array}{l}\text { Pre/postoperative } \\
\text { Pre/post- } \\
\text { radiotherapy/ } \\
\text { Chemotherapy }\end{array}$ & $\begin{array}{l}\text { Centrifugation } \\
\text { magnetic } \\
\text { separation of } \\
\text { beads }\end{array}$ & $\begin{array}{l}\text { Immunostaining } \\
\text { GEP8-FISH } \\
\text { CD45-, } \\
\text { GEP8+, GFAP-/+ }\end{array}$ & $\begin{array}{l}N=24 / 31 \\
\text { CTCs }=1-10 / 7.5 \\
\text { ml } \\
\text { No statistically } \\
\text { significant } \\
\text { difference } \\
\text { with grades }\end{array}$ & $\begin{array}{l}n=1 / 9 \\
\text { After- } \\
\text { surgery/radiotherapy/ } \\
\text { Chemotherapy } \\
\text { CTC }=1 / 7.5 \mathrm{ml}\end{array}$ & $P<0.01$ & NA \\
\hline $\begin{array}{l}\text { Sullivan } \\
\text { et al. (52) }\end{array}$ & $\begin{array}{l}\text { Blood } \\
10-20 \mathrm{ml}\end{array}$ & $\begin{array}{l}\text { GBM } \\
33 / 6\end{array}$ & Pre/postoperative & $\begin{array}{l}\text { CTC-iChip } \\
\text { (magnetically } \\
\text { tagged } \\
\text { CD45/CD16) }\end{array}$ & $\begin{array}{l}\text { Isolate single } \\
\text { CTCs } \\
\text { IHC glioma marker } \\
\text { panel (STEAM) } \\
\text { STEAM+, CD45- }\end{array}$ & $\begin{array}{l}n=13 / 33 \\
\text { CTCs }=11.8 \\
\text { (12 progressive) } \\
\text { CTCs }=2.1(21 \\
\text { stable) } \\
(>7 \text { CTCs } / \mathrm{ml})+\end{array}$ & NA & $P<0.001$ & NA \\
\hline $\begin{array}{l}\text { Bang- } \\
\text { Christensen } \\
\text { et al. (55) }\end{array}$ & $\begin{array}{l}\text { Blood } \\
3 \mathrm{ml}\end{array}$ & $\begin{array}{l}\text { WHO II-IV } \\
\text { 10/NA }\end{array}$ & NA & $\begin{array}{l}\text { Erythrocyte lysis } \\
\text { Centrifugation } \\
\text { Incubated with } \\
\text { rVAR2-coated } \\
\text { magnetic beads }\end{array}$ & $\begin{array}{l}\text { Immunostaining } \\
\text { DAPI+, CD45/CD66b- } \\
\text {,rVAR2+ }\end{array}$ & $\begin{array}{l}n=10 / 10 \\
\text { CTCs }= \\
0.5-42 / 3 \mathrm{ml} \\
\text { No statistically } \\
\text { significant } \\
\text { difference } \\
\text { with grades }\end{array}$ & NA & NA & NA \\
\hline $\begin{array}{l}\text { Zhang et al. } \\
\text { (57) }\end{array}$ & $\begin{array}{l}\text { Blood } \\
4 \mathrm{ml}\end{array}$ & $\begin{array}{l}\text { WHO II-IV } \\
39 / 178\end{array}$ & NA & $\begin{array}{l}\text { Erythrocyte lysis } \\
\text { Centrifugation } \\
\text { Resuspended with } \\
\text { oHSV1-hTERT- } \\
\text { GFP } \\
\text { and anti-CD45 }\end{array}$ & $\begin{array}{l}\text { Flow cytometry } \\
\text { CD45-/GFP+ }\end{array}$ & $\begin{array}{l}n=23 / 39 \text { CTCs } \\
=6.5 / 4 \mathrm{ml} \\
(>3 C T C s / 4 \mathrm{ml})+\end{array}$ & NA & NA & NA \\
\hline $\begin{array}{l}\text { Krol et al. } \\
\text { (58) }\end{array}$ & $\begin{array}{l}\text { Blood } \\
10 \mathrm{ml}\end{array}$ & $\begin{array}{l}\text { GBM } \\
13 / 3\end{array}$ & $\begin{array}{l}\text { Drug (BAL101553) } \\
\text { pre-dose (7d, 0 h) } \\
\text { post-dose (2h, } \\
24 \mathrm{~h}, 8 \mathrm{~d}, 22 \mathrm{~d})\end{array}$ & $\begin{array}{l}\text { Parsortix } \\
\text { microfluidic } \\
\text { device }\end{array}$ & $\begin{array}{l}\text { Immunostaining } \\
\text { EGFR+, Ki67+, } \\
\text { EB1+, CD45- }\end{array}$ & $\begin{array}{l}n=7 / 10 \\
(>3 \mathrm{CTCs} / 10 \mathrm{ml})+\end{array}$ & $\begin{array}{l}\text { Pre }=12 \text { CTCs } \\
\text { Post }=14 \text { CTCs }\end{array}$ & $P=0.462$ & NA \\
\hline
\end{tabular}

T, tumor; N, Normal; RT, radiotherapy; GBM, glioblastoma; MNCs, monocytes; NA, Not mentioned. 
TABLE 2 | Advantages and disadvantages of the detection of the CTCs.

\begin{tabular}{|c|c|c|}
\hline Techniques & Advantages & Disadvantages \\
\hline Kojima et al. (26) & $\begin{array}{l}\text { Simple, convenient, Easy to operate } \\
\text { GFAP-positive cells be used for gene sequencing analysis }\end{array}$ & $\begin{array}{l}\text { Detection rate is low }(20.6 \%, 29 / 141) \\
\text { GFAP expression is not totally restricted to glial cells, } \\
\text { such as hepatic stellate cells } \\
\text { Insufficient sample size, Detection is limited to GBM }\end{array}$ \\
\hline MacArthur et al. (27) & $\begin{array}{l}\text { High sensitivity } \\
\text { Telomerase not expressed in highly differentiated and normal cells } \\
\text { Epithelial cell marker independent }\end{array}$ & $\begin{array}{l}\text { Operation is complicated and expensive } \\
\text { Insufficient sample size, Detection is limited to GBM } \\
\text { Unable to mark genetic phenotype }\end{array}$ \\
\hline Gao et al. (20) & $\begin{array}{l}\text { Good sensitivity and specificity } \\
\text { Detection in multiple grades of glioma } \\
\text { Not depend on physical and chemical characteristics } \\
\text { Polyploidy rate reflects the degree of malignancy }\end{array}$ & $\begin{array}{l}\text { Operation is complicated and expensive } \\
\text { Insufficient sample size }\end{array}$ \\
\hline Sullivan et al. (52) & $\begin{array}{l}\text { High sensitivity } \\
\text { Determine the molecular typing and genetic profiling }\end{array}$ & $\begin{array}{l}\text { Detection rate is low }(39.3 \%, 13 / 33) \\
\text { Insufficient sample size, Detection is limited to GBM } \\
\text { Increases the risk of false positives and high } \\
\text { background levels }\end{array}$ \\
\hline $\begin{array}{l}\text { Bang-Christensen et al. } \\
\text { (55) }\end{array}$ & $\begin{array}{l}\text { High detection rate }(100 \%, 10 / 10) \\
\text { Determine the molecular typing and genetic profiling }\end{array}$ & $\begin{array}{l}\text { Insufficient sample size } \\
\text { Increases the risk of false positives }\end{array}$ \\
\hline Zhang et al. (57) & $\begin{array}{l}\text { High sensitivity } \\
\text { Epithelial cell marker independent } \\
\text { Determine the molecular typing and genetic profiling }\end{array}$ & $\begin{array}{l}\text { Insufficient sample size } \\
\text { Unstable detection }\end{array}$ \\
\hline Krol et al. (58) & $\begin{array}{l}\text { High separation efficiency, simple operation and extremely low cost } \\
\text { High sensitivity }\end{array}$ & Insufficient sample size \\
\hline
\end{tabular}

proneural (PN), and neural (66). The classic GBM shows high proliferation characteristics, often accompanied by high-level EGFR amplification. MQ is defined by overexpression of markers of MQ (CHI3L1/YKL40 and MET) and astrocytes (CD44 and MERTK), plus deletion or mutation of NF1 (17q11.2). PN show simultaneous activation of oligodendrocytes (PDGFRA, OLIG2, TCF3, NKX2-2) and PN (SOX, DCX, DLL3, ASCL1, TCF4) development-related genes, and are characterized by molecular changes in TP53, PDGFRA, and PIK3CA/PIK3R1 and IDH1 mutations. Neural-GBM lack a unique genetic map showing gene expression characteristics similar to those in normal brain tissue, and expressed neuronal markers such as NEFL, GABRA1, SYT1, and SLC12A5 (67-70).

Sullivan et al. (52) found that CTCs detected in GBM patients overexpress interstitial transcription proteins, and showed the transcriptional characteristics of mesenchymal GBMs. Neural/mesenchymal RNA-ISH assay showed that primary subpopulations of GBM cells which expressing high interstitial expression profiles were more likely to invade the bloodstream. These observations increase the possibility that MQ-GBMs will more easily enter the vascular lumen of the brain and circulate through the systemic vascular system.

\section{Clinical Value of CTCs}

At present, there are few studies on CTCs in gliomas, and its clinical value cannot be fully determined due to unclear detection methods and insufficient clinical sample sizes. But the current research still yields some promising results.

Gao et al. detected CTCs in all glioma pathological subtypes (astrocytoma; oligodendroglioma; oligoastrocytoma; anaplastic astrocytoma; anaplastic oligodendroglioma; anaplastic oligoastrocytoma; GBM), and the number of CTCs increased with increasing malignancy; Muller's study found that the number of CTCs in patients after chemotherapy or radiotherapy was significantly lower than before, CTCs detection results were always consistent with the MRI findings in both radionecrosis and progression. CTCs can be regarded as a complement of MRI and it, to some extent, is superior to MRI in monitoring the treatment response and local microenvironment of glioma; James et al. tested the expression characteristics of a single CTC, which provided the possibility to determine the molecular characteristics of gliomas, and it is possible to determine the patient's pathological type and develop a treatment plan without invasive operations $(20,22,52)$.

Almost all studies found that the CTCs count before and after the operation were basically the same, which may indicate that the surgical operation did not lead to the release of CTCs. Due to the shortage of sample size and follow-up time, the relationship between CTCs and disease progression and survival has not been observed. The challenge in limiting the use of CTC detection for gliomas in clinical applications lies in the complexity and low sensitivity of the detection technology. But there is no doubt that CTC has a incredible application prospect in intracranial malignancies.

\section{RESEARCH CHALLENGES OF CTCs IN GLIOMA}

\section{Blood-Brain Barrier Escape Mechanism}

In the past few decades, the application of CTCs has not received much attention in glioma. Malignant glioma is highly aggressive, but its extracranial metastasis is rare. Because of the blood-brain barrier, there is a misconception that glioma cells can never enter 
the blood circulation. And recent researches have overturned this conclusion. So far, the mechanism of CTCs escape from the blood-brain barrier has not been fully elucidated.

Studies have suggested that some characteristics of CTCs may be the reason for their aggressiveness. CTCs that expressing high interstitial characteristics are more likely to invade the bloodstream (52). Some characteristics of GBM also help CTCs to enter the bloodstream and spread further throughout the body. GBM has the highest degree of vascularization compared to other types of tumors, and studies have found that the integrity of the blood-brain barrier in GBM patients is damaged, there are multiple windows and damaged tight connections $(71,72)$. Current findings are limited to GBM. It is worth noting that there is still a lack of comprehensive and in-depth understanding of this mechanism, especially in gliomas with lower WHO classification.

\section{Rare Extracranial Metastases}

Although glioma cells can invade the bloodstream, they rarely turn into metastatic lesions outside the brain. Several reasons for low incidence of extracranial metastases of glioma have been discussed, include: Short survival time of patients, especially GBM; the Blood-brain barrier; the immune system inhibits the extracranial growth of glioma cells (73); There is no lymphatic channel in the central nervous system (74), or glioma cells cannot invade the connective stroma (75). Research by Yu et al. found that tumor cells can express PTEN (an important tumor suppressor) in peripheral organs, but once transplanted into the brain, the expression of PETN decreases (76). And in the brain, exosomes secreted by glial cells can create a unique fertile environment suitable for the growth of cancer seeds (77-79). We guess that there are some inherent changes in CTCs that can limit the extracranial metastasis of gliomas. Changes in some epitope factors may occur when CTCs cross the blood-brain barrier. This is just our guess and needs further research to verify.

But this does not mean that it does not need to be taken seriously. There are still case reports of extracranial metastasis of glioma. Davis (80) for the first time fully reported cases of glioma concurrent with extracranial metastasis. Chang et al. (81) present a pathologically proven patient with scalp metastasis, which was metastasized from LGG occurring site to the surgical scar. And GBM metastases to the masticatory muscles and the scalp (82). There was even a case of a female patient with a known glioblastoma who was detected to harbor multiple metastases in the bones, lung, pleura, liver, mesentery, and the subcutaneous soft tissue (83). As the life span of patients with glioma increases after treatment, it is of great significance for detecting extracranial metastases. The research on CTC is hopeful to be an auxiliary diagnostic method for evaluating extracranial metastases in patients, and can be routinely screened for extracranial metastases in patients with glioma in clinical practice.

\section{Research on CTCs in Brain Metastases}

In addition to gliomas, brain metastases account for a large proportion of intracranial malignant tumors. In non-small cell lung cancer (NSCLC), tumors metastasize most frequently to brain (40\%) (84). $15-30 \%$ of patients with metastatic breast cancer will develop brain metastases during the course of the disease (85). Lung and breast cancer brain metastases are more commonly diagnosed than primary brain tumors. The formation of metastasis is the limiting factor of survival for most carcinoma patients. And Brain metastasis has devastating prognosis and accounts for significant morbidity and mortality in cancer patients (86). Brain metastasis are not only associated with an extremely poor prognosis but also with neurological impairments by often affecting both cognitive and sensory functions. Therefore, Brain metastasis have become a major limitation of life expectancy and quality of life in many patients.

Metastases originate from single or multiple tumor cells, circulating tumor cells (CTCs), which can initially be separated from the primary lesion, survive in the peripheral circulation and settle in distant target tissues (87). Studies have found that patients (NSCLC, colon cancer, SCLC, ovarian cancer, and renal cell carcinoma) with brain metastases have fewer CTCs than those with other metastases, and oligo- Metastatic patients have fewer peripheral blood CTC counts than multiple metastases (88). The number of CTCs in patients after brain metastasis resection is lower than that of patients without surgery or only radiotherapy and chemotherapy, and the number of CTC is significantly related to the survival of patients with brain metastases. These results indicate that the location and number of metastases have a strong influence on the number of CTCs. The detection of CTC has important clinical value for assessing the survival of patients with brain metastases, and even for identifying patients with brain metastases who may benefit from stronger treatments.

In addition, the recycling of CTCs from distant metastatic sites is also important. The recycling of CTCs seems to be more effective from other parts than the brain. This may be related to the existence of the blood-brain barrier, and some studies also speculate that a higher proportion of CTCs in patients with brain metastases may have undergone the epithelial-to-mesenchymal transition and cannot be detected (88). Carlotta et al. analyzed the copy number alteration (CNA) profiles of CTCs as well as autologous tumor tissue (89). Study has found that CTCs are similar to the corresponding primary breast tumors, but also found important pathway changes in brain metastasis, including notch (increased NOTCH3) and PI3K (increased PDPK1) pathways $(90,91)$. At the same time, the tumor cells metastasized to the brain have undergone strict clonal selection so that most of the CTCs in patients with brain metastasis exhibit a high degree of clonality. However, further studies need to be performed to validate these results. Research on CTC is not only helpful in evaluating the prognosis and treatment of patients with brain metastases, but also in understanding the complex mechanisms of brain metastasis at the molecular level.

\section{CONCLUSION}

So far, there is limited data on CTC and brain tumors, and the application of CTC as a biomarker for glioma patients has only just begun. The identification of CTC has important clinical application value for early tumor diagnosis and prognosis. The 
integration of CTC and its molecular features in clinical practice may help to establish a diagnosis in a non-invasive manner and suggest complex tumor treatments without the need for highrisk neurosurgical intervention. The wide application prospect of CTC in glioma deserves further exploration, and the research on more sensitive and convenient detection methods is necessary.

\section{SEARCH STRATEGY AND SELECTION CRITERIA}

Data for this Review were identified by searches of PubMed, and references from relevant articles using the search terms "Gliomas," "Circulating tumor cells," and "liquid biopsy."

\section{REFERENCES}

1. Ferlay J, Colombet M, Soerjomataram I, Mathers C, Parkin DM, Pineros M, et al. Estimating the global cancer incidence and mortality in 2018: GLOBOCAN sources and methods. Int J Cancer. (2019) 144:1941-53. doi: $10.1002 / \mathrm{ijc} .31937$

2. Ohgaki H, Kleihues P. Population-based studies on incidence, survival rates, and genetic alterations in astrocytic and oligodendroglial gliomas. $J$ Neuropathol Exp Neurol. (2005) 64:479-89. doi: 10.1093/jnen/64.6.479

3. Ohgaki H, Kleihues P. Genetic pathways to primary and secondary glioblastoma. Am J Pathol. (2007) 170:1445-53. doi: 10.2353/ajpath. 2007.070011

4. Ostrom QT, Gittleman H, Truitt G, Boscia A, Kruchko C, Barnholtz-Sloan JS. CBTRUS statistical report: primary brain and other central nervous system tumors diagnosed in the United States in 2011-2015. Neuro Oncol. (2018) 20:iv1-86. doi: 10.1093/neuonc/noyl31

5. Macdonald DR, Cascino TL, Schold SC, Jr., Cairncross JG. Response criteria for phase II studies of supratentorial malignant glioma. J Clin Oncol. (1990) 8:1277-80. doi: 10.1200/JCO.1990.8.7.1277

6. Wen PY, Macdonald DR, Reardon DA, Cloughesy TF, Sorensen AG, Galanis E, et al. Updated response assessment criteria for high-grade gliomas: response assessment in neuro-oncology working group. J Clin Oncol. (2010) 28:196372. doi: 10.1200/JCO.2009.26.3541

7. Brandsma D, Stalpers L, Taal W, Sminia P, van den Bent MJ. Clinical features, mechanisms, and management of pseudoprogression in malignant gliomas. Lancet Oncol. (2008) 9:453-61. doi: 10.1016/S1470-2045(08)70125-6

8. Brandsma D, van den Bent MJ. Pseudoprogression and pseudoresponse in the treatment of gliomas. Curr Opin Neurol. (2009) 22:633-8. doi: 10.1097/WCO.0b013e328332363e

9. Klekner A, Szivos L, Virga J, Arkosy P, Bognar L, Birko Z, et al. Significance of liquid biopsy in glioblastoma - a review. J Biotechnol. (2019) 298:82-7. doi: 10.1016/j.jbiotec.2019.04.011

10. Kros JM, Mustafa DM, Dekker LJ, Sillevis Smitt PA, Luider TM, Zheng PP. Circulating glioma biomarkers. Neuro Oncol. (2015) 17:343-60. doi: 10.1093/neuonc/nou207

11. Shim S, Stemke-Hale K, Tsimberidou AM, Noshari J, Anderson TE, Gascoyne PR. Antibody-independent isolation of circulating tumor cells by continuous-flow dielectrophoresis. Biomicrofluidics. (2013) 7:11807. doi: $10.1063 / 1.4774304$

12. Thege FI, Lannin TB, Saha TN, Tsai S, Kochman ML, Hollingsworth MA, et al. Microfluidic immunocapture of circulating pancreatic cells using parallel EpCAM and MUC1 capture: characterization, optimization and downstream analysis. Lab Chip. (2014) 14:1775-84. doi: 10.1039/C4LC 00041B

13. Yoon HJ, Kozminsky M, Nagrath S. Emerging role of nanomaterials in circulating tumor cell isolation and analysis. ACS Nano. (2014) 8:1995-2017. doi: $10.1021 / \mathrm{nn} 5004277$

14. Gupta GP, Massague J. Cancer metastasis: building a framework. Cell. (2006) 127:679-95. doi: 10.1016/j.cell.2006.11.001
Only articles published in English between 1990 and 2020 were included.

\section{AUTHOR CONTRIBUTIONS}

$\mathrm{HZ}$ collected data and wrote the paper. HZ, FQ, and YQ collect literature and information. QC and BL reviewed the paper. All authors read and approved the final manuscript.

\section{FUNDING}

This work was supported by the National Natural Science Foundation of China (No. 81572489, 81372683, and 81502075).

15. Kim YN, Koo KH, Sung JY, Yun UJ, Kim H. Anoikis resistance: an essential prerequisite for tumor metastasis. Int J Cell Biol. (2012) 2012:306879. doi: 10.1155/2012/306879

16. Luzzi KJ, MacDonald IC, Schmidt EE, Kerkvliet N, Morris VL, Chambers AF, et al. Multistep nature of metastatic inefficiency: dormancy of solitary cells after successful extravasation and limited survival of early micrometastases. Am J Pathol. (1998) 153:865-73.

17. Lee JS, Magbanua MJM, Park JW. Circulating tumor cells in breast cancer: applications in personalized medicine. Breast Cancer Res Treat. (2016) 160:411-24. doi: 10.1007/s10549-016-4014-6

18. Pak S, Suh YS, Lee DE, Kim SH, Joung JY, Park WS, et al. Association between postoperative detection of circulating tumor cells and recurrence in patients with prostate cancer. J Urol. (2020) 203:1128-34. doi: 10.1097/JU.0000000000000704

19. Ross K, Pailler E, Faugeroux V, Taylor M, Oulhen M, Auger N, et al. The potential diagnostic power of circulating tumor cell analysis for non-small-cell lung cancer. Expert Rev Mol Diagn. (2015) 15:1605-29. doi: 10.1586/14737159.2015.1111139

20. Gao F, Cui Y, Jiang H, Sui D, Wang Y, Jiang Z, et al. Circulating tumor cell is a common property of brain glioma and promotes the monitoring system. Oncotarget. (2016) 7:71330-40. doi: 10.18632/oncotarget.11114

21. Armstrong TS, Prabhu S, Aldape K, Hossan B, Kang S, Childress A, et al. A case of soft tissue metastasis from glioblastoma and review of the literature. $J$ Neurooncol. (2011) 103:167-72. doi: 10.1007/s11060-010-0370-y

22. Muller C, Holtschmidt J, Auer M, Heitzer E, Lamszus K, Schulte A, et al. Hematogenous dissemination of glioblastoma multiforme. Sci Transl Med. (2014) 6:247ra101. doi: 10.1126/scitranslmed.3009095

23. Eng LF, Ghirnikar RS, Lee YL. Glial fibrillary acidic protein: GFAP-thirty-one years (1969-2000). Neurochem Res. (2000) 25:1439-51.

24. Jung CS, Foerch C, Schanzer A, Heck A, Plate KH, Seifert V, et al. Serum GFAP is a diagnostic marker for glioblastoma multiforme. Brain. (2007) 130:3336-41. doi: 10.1093/brain/awm263

25. Lim MC, Maubach G, Zhuo L. Glial fibrillary acidic protein splice variants in hepatic stellate cells-expression and regulation. Mol Cells. (2008) 25:376-84.

26. Kojima T, Hashimoto Y, Watanabe Y, Kagawa S, Uno F, Kuroda S, et al. A simple biological imaging system for detecting viable human circulating tumor cells. J Clin Invest. (2009) 119:3172-81. doi: 10.1172/JCI38609

27. Macarthur KM, Kao GD, Chandrasekaran S, Alonso-Basanta M, Chapman C, Lustig RA, et al. Detection of brain tumor cells in the peripheral blood by a telomerase promoter-based assay. Cancer Res. (2014) 74:2152-9. doi: 10.1158/0008-5472.CAN-13-0813

28. Corbett N, Alda M. On telomeres long and short. J Psychiatry Neurosci. (2015) 40:3-4. doi: 10.1503/jpn.140347

29. Hannen R, Bartsch JW. Essential roles of telomerase reverse transcriptase hTERT in cancer stemness and metastasis. FEBS Lett. (2018) 592:2023-31. doi: 10.1002/1873-3468.13084

30. Maciejowski J, de Lange T. Telomeres in cancer: tumour suppression and genome instability. Nat Rev Mol Cell Biol. (2017) 18:175-86. doi: $10.1038 / \mathrm{nrm} .2016 .171$ 
31. Eskilsson E, Rosland GV, Solecki G, Wang Q, Harter PN, Graziani G, et al. EGFR heterogeneity and implications for therapeutic intervention in glioblastoma. Neuro Oncol. (2018) 20:743-52. doi: 10.1093/neuonc/nox191

32. Lv D, Lu L, Hu Z, Fei Z, Liu M, Wei L, et al. Nestin expression is associated with poor clinicopathological features and prognosis in glioma patients: an association study and meta-analysis. Mol Neurobiol. (2017) 54:727-35. doi: 10.1007/s12035-016-9689-5

33. Saadeh FS, Mahfouz R, Assi HI. EGFR as a clinical marker in glioblastomas and other gliomas. Int J Biol Markers. (2018) 33:22-32. doi: 10.5301/ijbm.5000301

34. Erfani P, Tome-Garcia J, Canoll P, Doetsch F, Tsankova NM. EGFR promoter exhibits dynamic histone modifications and binding of ASH2L and P300 in human germinal matrix and gliomas. Epigenetics. (2015) 10:496-507. doi: 10.1080/15592294.2015.1042645

35. Fang BJ, Geng FY, Lu FQ, Wang YH, Zhang LQ, Meng FG. Expression and clinical significance of nestin in astrocytic tumors. J BUON. (2016) 21:191-8.

36. Garcia-Blanco A, Bulnes S, Pomposo I, Carrasco A, Lafuente JV. Nestin+cells forming spheroids aggregates resembling tumorspheres in experimental ENU-induced gliomas. Histol Histopathol. (2016) 31:1347-56. doi: 10.14670/HH-11-763

37. Castro MA, Onsten TG, Moreira JC, de Almeida RM. Chromosome aberrations in solid tumors have a stochastic nature. Mutat Res. (2006) 600:150-64. doi: 10.1016/j.mrfmmm.2006.04.003

38. Kops GJ, Weaver BA, Cleveland DW. On the road to cancer: aneuploidy and the mitotic checkpoint. Nat Rev Cancer. (2005) 5:773-85. doi: $10.1038 / \mathrm{nrc17} 14$

39. Sansregret L, Swanton C. The role of aneuploidy in cancer evolution. Cold Spring Harb Perspect Med. (2017) 7:a028373. doi: 10.1101/cshperspect.a028373

40. Mandrioli D, Belpoggi F, Silbergeld EK, Perry MJ. Aneuploidy: a common and early evidence-based biomarker for carcinogens and reproductive toxicants. Environ Health. (2016) 15:97. doi: 10.1186/s12940-016-0180-6

41. Sen S. Aneuploidy and cancer. Curr Opin Oncol. (2000) 12:82-8. doi: 10.1097/00001622-200001000-00014

42. Lengauer C, Kinzler KW, Vogelstein B. Genetic instabilities in human cancers. Nature. (1998) 396:643-9. doi: 10.1038/25292

43. Holliday R. Chromosome error propagation and cancer. Trends Genet. (1989) 5:42-5. doi: 10.1016/0168-9525(89)90020-6

44. De Grouchy J. [Chromosome aberrations and carcinogenesis]. Med Infant. (1963) 70:601-6.

45. Duensing A, Duensing S. Guilt by association? p53 and the development of aneuploidy in cancer. Biochem Biophys Res Commun. (2005) 331:694-700. doi: 10.1016/j.bbrc.2005.03.157

46. Cappuzzo F, Varella-Garcia M, Rossi E, Gajapathy S, Valente M, Drabkin $\mathrm{H}$, et al. MYC and EIF3H coamplification significantly improve response and survival of non-small cell lung cancer patients (NSCLC) treated with gefitinib. J Thorac Oncol. (2009) 4:472-8. doi: 10.1097/JTO.0b013e3181 9 a5767

47. Griffin CA, Morsberger L, Hawkins AL, Haddadin M, Patel A, Ried T, et al. Molecular cytogenetic characterization of pancreas cancer cell lines reveals high complexity chromosomal alterations. Cytogenet Genome Res. (2007) 118:148-56. doi: 10.1159/000108295

48. Sanchez-Perez I, Garcia Alonso P, Belda Iniesta C. Clinical impact of aneuploidy on gastric cancer patients. Clin Transl Oncol. (2009) 11:493-8. doi: 10.1007/s12094-009-0393-Z

49. Steiner MG, Harlow SP, Colombo E, Bauer KD. Chromosomes 8, 12, and 17 copy number in Astler-Coller stage $\mathrm{C}$ colon cancer in relation to proliferative activity and DNA ploidy. Cancer Res. (1993) 53:681-6.

50. Acar H, Kilinc M, Yildirim MS, Kaynak M, Cenker A. Evaluation of chromosome 8 and 11 aneuploidies in washings and biopsy materials of bladder transitional cell carcinoma. Cancer Genet Cytogenet. (2003) 142:25-9. doi: 10.1016/S0165-4608(02)00803-8

51. Ozkumur E, Shah AM, Ciciliano JC, Emmink BL, Miyamoto DT, Brachtel $\mathrm{E}$, et al. Inertial focusing for tumor antigen-dependent and -independent sorting of rare circulating tumor cells. Sci Transl Med. (2013) 5:179ra47. doi: 10.1126/scitranslmed.3005616

52. Sullivan JP, Nahed BV, Madden MW, Oliveira SM, Springer S, Bhere D, et al. Brain tumor cells in circulation are enriched for mesenchymal gene expression. Cancer Discov. (2014) 4:1299-309. doi: 10.1158/2159-8290.CD-14-0471

53. Agerbaek MO, Bang-Christensen SR, Yang MH, Clausen TM, Pereira MA, Sharma S, et al. The VAR2CSA malaria protein efficiently retrieves circulating tumor cells in an EpCAM-independent manner. Nat Commun. (2018) 9:3279. doi: 10.1038/s41467-018-05793-2

54. Salanti A, Clausen TM, Agerbaek MO, Al Nakouzi N, Dahlback M, Oo $\mathrm{HZ}$, et al. Targeting human cancer by a glycosaminoglycan binding malaria protein. Cancer Cell. (2015) 28:500-14. doi: 10.1016/j.ccell.2015.09.003

55. Bang-Christensen SR, Pedersen RS, Pereira MA, Clausen TM, Loppke C, Sand NT, et al. Capture and detection of circulating glioma cells using the recombinant VAR2CSA malaria protein. Cells. (2019) 8:998. doi: 10.3390/cells 8090998

56. Adusumilli PS, Gholami S, Chun YS, Mullerad M, Chan MK, Yu Z, et al. Fluorescence-assisted cytological testing (FACT): ex vivo viral method for enhancing detection of rare cancer cells in body fluids. Mol Med. (2011) 17:628-34. doi: 10.2119/molmed.2011.00078

57. Zhang W, Bao L, Yang S, Qian Z, Dong M, Yin L, et al. Tumor-selective replication herpes simplex virus-based technology significantly improves clinical detection and prognostication of viable circulating tumor cells. Oncotarget. (2016) 7:39768-83. doi: 10.18632/oncotarget.9465

58. Krol I, Castro-Giner F, Maurer M, Gkountela S, Szczerba BM, Scherrer R, et al. Detection of circulating tumour cell clusters in human glioblastoma. $\mathrm{Br}$ J Cancer. (2018) 119:487-91. doi: 10.1038/s41416-018-0186-7

59. Islam M, Sajid A, Mahmood MA, Bellah MM, Allen PB, Kim YT, et al. Nanotextured polymer substrates show enhanced cancer cell isolation and cell culture. Nanotechnology. (2015) 26:225101. doi: 10.1088/0957-4484/26/22/225101

60. Gao R, Cheng L, Wang S, Bi X, Wang X, Wang R, et al. Efficient separation of tumor cells from untreated whole blood using a novel multistage hydrodynamic focusing microfluidics. Talanta. (2020) 207:120261. doi: 10.1016/j.talanta.2019.120261

61. Liu T, Xu H, Huang M, Ma W, Saxena D, Lustig RA, et al. Circulating glioma cells exhibit stem cell-like properties. Cancer Res. (2018) 78:6632-42. doi: 10.1158/0008-5472.CAN-18-0650

62. Clarke MF, Dick JE, Dirks PB, Eaves CJ, Jamieson CH, Jones DL, et al. Cancer stem cells-perspectives on current status and future directions: AACR Workshop on cancer stem cells. Cancer Res. (2006) 66:9339-44. doi: 10.1158/0008-5472.CAN-06-3126

63. Sakariassen PO, Immervoll H, Chekenya M. Cancer stem cells as mediators of treatment resistance in brain tumors: status and controversies. Neoplasia. (2007) 9:882-92. doi: 10.1593/neo.07658

64. Ishikawa M, Sumita K, Tamura K, Kobayashi D, Tsukahara Y, Inaji M, et al. [Cerebellar glioblastoma with intrathecal dissemination:a report of four cases]. No Shinkei Geka. (2020) 48:237-44. doi: 10.11477/mf.1436204169

65. Sandberg CJ, Altschuler G, Jeong J, Stromme KK, Stangeland B, Murrell $\mathrm{W}$, et al. Comparison of glioma stem cells to neural stem cells from the adult human brain identifies dysregulated Wnt- signaling and a fingerprint associated with clinical outcome. Exp Cell Res. (2013) 319:2230-43. doi: 10.1016/j.yexcr.2013.06.004

66. Crespo I, Vital AL, Gonzalez-Tablas M, Patino Mdel C, Otero A, Lopes MC, et al. Molecular and genomic alterations in glioblastoma multiforme. Am J Pathol. (2015) 185:1820-33. doi: 10.1016/j.ajpath.2015.02.023

67. Yamini B. NF-kappaB, mesenchymal differentiation and glioblastoma. Cells. (2018) 7:125. doi: 10.3390/cells7090125

68. Verhaak RG, Hoadley KA, Purdom E, Wang V, Qi Y, Wilkerson MD, et al. Integrated genomic analysis identifies clinically relevant subtypes of glioblastoma characterized by abnormalities in PDGFRA, IDH1, EGFR, and NF1. Cancer Cell. (2010) 17:98-110. doi: 10.1016/j.ccr.2009.12.020

69. Brennan CW, Verhaak RG, McKenna A, Campos B, Noushmehr H, Salama SR, et al. The somatic genomic landscape of glioblastoma. Cell. (2013) 155:462-77. doi: 10.1016/j.cell.2013.09.034

70. Ohgaki H, Kleihues $\mathrm{P}$. The definition of primary and secondary glioblastoma. Clin Cancer Res. (2013) 19:764-72. doi: 10.1158/1078-0432.CCR-12-3002

71. Hirano A, Matsui T. Vascular structures in brain tumors. Hum Pathol. (1975) 6:611-21. doi: 10.1016/S0046-8177(75)80045-1

72. Takano S, Yamashita T, Ohneda O. Molecular therapeutic targets for glioma angiogenesis. J Oncol. (2010) 2010:351908. doi: 10.1155/2010/351908 
73. Fonkem E, Lun M, Wong ET. Rare phenomenon of extracranial metastasis of glioblastoma. J Clin Oncol. (2011) 29:4594-5. doi: 10.1200/JCO.2011.39.0187

74. Pasquier B, Pasquier D, Lachard A, N'Golet A, Panh MH, Couderc P. [Extraneural metastasis of central nervous system tumours (author's transl)]. Bull Cancer. (1979) 66:25-8.

75. Pansera F, Pansera E. An explanation for the rarity of extraaxial metastases in brain tumors. Med Hypotheses. (1992) 39:88-9. doi: 10.1016/0306-9877(92)90146-4

76. Zhang L, Zhang S, Yao J, Lowery FJ, Zhang Q, Huang WC, et al. Microenvironment-induced PTEN loss by exosomal microRNA primes brain metastasis outgrowth. Nature. (2015) 527:100-4. doi: 10.1038/nature15376

77. Yuyama K, Igarashi Y. Physiological and pathological roles of exosomes in the nervous system. Biomol Concepts. (2016) 7:53-68. doi: 10.1515/bmc-2015-0033

78. Murgoci AN, Cizkova D, Majerova P, Petrovova E, Medvecky L, Fournier I, et al. Brain-cortex microglia-derived exosomes: nanoparticles for glioma therapy. Chemphyschem. (2018) 19:1205-14. doi: 10.1002/cphc.201701198

79. Iorgulescu JB, Ivan ME, Safaee M, Parsa AT. The limited capacity of malignant glioma-derived exosomes to suppress peripheral immune effectors. J Neuroimmunol. (2016) 290:103-8. doi: 10.1016/j.jneuroim.2015.11.025

80. Pasquier B, Pasquier D, N'Golet A, Panh MH, Couderc P. Extraneural metastases of astrocytomas and glioblastomas: clinicopathological study of two cases and review of literature. Cancer. (1980) 45:112-25. doi: 10.1002/ 1097-0142(19800101)45:1<112::AID-CNCR2820450121>3.0.CO;2-9

81. Chang H, Ding Y, Wang $\mathrm{P}$, Wang Q, Lin Y, Li B. Cutaneous metastases of the glioma. J Craniofac Surg. (2018) 29:e94-e6. doi: 10.1097/SCS.0000000000004204

82. Perez-Bovet J, Rimbau-Munoz J. Glioblastoma multiforme metastases to the masticator muscles and the scalp. J Clin Neurosci. (2018) 53:237-9. doi: 10.1016/j.jocn.2018.04.021

83. Rosen J, Blau T, Grau SJ, Barbe MT, Fink GR, Galldiks N. Extracranial metastases of a cerebral glioblastoma: a case report and review of the literature. Case Rep Oncol. (2018) 11:591-600. doi: 10.1159/000492111

84. Riihimaki M, Hemminki A, Fallah M, Thomsen H, Sundquist K, Sundquist J, et al. Metastatic sites and survival in lung cancer. Lung Cancer. (2014) 86:78-84. doi: 10.1016/j.lungcan.2014.07.020
85. Tabouret E, Chinot O, Metellus P, Tallet A, Viens P, Goncalves A. Recent trends in epidemiology of brain metastases: an overview. Anticancer Res. (2012) 32:4655-62.

86. Maher EA, Mietz J, Arteaga CL, DePinho RA, Mohla S. Brain metastasis: opportunities in basic and translational research. Cancer Res. (2009) 69:601520. doi: 10.1158/0008-5472.CAN-08-4347

87. Joosse SA, Gorges TM, Pantel K. Biology, detection, and clinical implications of circulating tumor cells. EMBO Mol Med. (2015) 7:1-11. doi: 10.15252/emmm.201303698

88. Hanssen A, Riebensahm C, Mohme M, Joosse SA, Velthaus JL, Berger LA, et al. Frequency of Circulating Tumor Cells (CTC) in patients with brain metastases: implications as a risk assessment marker in oligo-metastatic disease. Cancers. (2018) 10:527. doi: 10.3390/cancers10120527

89. Riebensahm C, Joosse SA, Mohme M, Hanssen A, Matschke J, Goy Y, et al. Clonality of circulating tumor cells in breast cancer brain metastasis patients. Breast Cancer Res. (2019) 21:101. doi: 10.1186/s13058-019-1184-2

90. Leontovich AA, Jalalirad M, Salisbury JL, Mills L, Haddox C, Schroeder $\mathrm{M}$, et al. NOTCH3 expression is linked to breast cancer seeding and distant metastasis. Breast Cancer Res. (2018) 20:105. doi: 10.1186/s13058-0181020-0

91. Maurer M, Su T, Saal LH, Koujak S, Hopkins BD, Barkley CR, et al. 3Phosphoinositide-dependent kinase 1 potentiates upstream lesions on the phosphatidylinositol 3-kinase pathway in breast carcinoma. Cancer Res. (2009) 69:6299-306. doi: 10.1158/0008-5472.CAN-09-0820

Conflict of Interest: The authors declare that the research was conducted in the absence of any commercial or financial relationships that could be construed as a potential conflict of interest.

Copyright (c) 2021 Zhang, Yuan, Qi, Liu and Chen. This is an open-access article distributed under the terms of the Creative Commons Attribution License (CC BY). The use, distribution or reproduction in other forums is permitted, provided the original author(s) and the copyright owner(s) are credited and that the original publication in this journal is cited, in accordance with accepted academic practice. No use, distribution or reproduction is permitted which does not comply with these terms. 